Doi: $10.4274 /$ vhd.0006

Viral Hepatitis Journal 2018;24(1):21-23

\title{
Epidemiology of Hepatitis C in North Cyprus
}

\section{Kuzey Kıbrıs'ta Hepatit C Epidemiyolojisi}

\author{
๑ Meryem GÜVENIR1' ๑ Kaya SÜER²
}

${ }^{1}$ Near East University, Vocational School of Health Services, Department of Microbiology, Lefkoşa, North Cyprus

2 Near East University Faculty of Medicine, Department of Infectious Disease and Clinical Microbiology, Lefkoşa, Northern Cyprus

\begin{abstract}
Hepatitis $\mathrm{C}$ virus $(\mathrm{HCV})$ is known as the main etiological agent of chronic liver disease, cirrhosis and hepatocellular carcinoma. Studies on the Turkish Republic of North Cyprus (TRNC) population have reported that the HCV prevalence was between $0 \%$ and $1 \%$. The low prevalence of $\mathrm{HCV}$ in the TRNC is a result of the small island population and the fact that HCV-positive individuals were not allowed to reside in the TRNC until 2017. However, it is likely that there will be an increase in HCV seroprevalence going forward due to relapses and cases of illegal immigration. The aim of this study was to review the HCV epidemiology in the TRNC in the light of the current data.

Keywords: Prevalence, hepatitis C virus infection, North Cyprus
\end{abstract}

\section{ÖZ}

Hepatit C virüsü (HCV), kronik karaciğer, siroz ve hepatosellüler karsinoma etkeni olduğu bilinmektedir. Kuzey Kıbrıs Türk Cumhuriyeti'nde (KKTC) yapılan çalışmalar prevelansın \%0-1 arasında olduğunu göstermektedir. Ülkemizde HCV insidansının düşük olmasının nedeni nüfus olarak küçük bir ada olmamız ve HCV pozitif olgulara 2017 yllına kadar KKTC'de ikamet etme izninin verilmemesi olduğunu ve HCV için yapılan düzenlemenin sonucunda relaps olguların ve ayrıca adada illegal kesimin bulunduğu göz önüne alınırsa HCV seroprevelansında da artış olabileceğini düşünmekteyiz. Bu makalede, KKTC'deki HCV epidemiyolojinin güncel literatür ile birikte gözden geçirilmesi amaçlanmıştır.

Anahtar Kelimeler: Prevalans, hepatit C virüs enfeksiyonları, Kuzey Kıbris

Güvenir M, Süer K. Epidemiology of Hepatitis C in North Cyprus. Viral Hepat J. 2018;24:21-23.

\section{Introduction}

Hepatitis C virus (HCV), a hepatotropic RNA virus, was discovered in 1989 (1). HCV is a small, enveloped, single-stranded, positive sense RNA virus belonging to the Flaviviridae genera Pegivirus (1,2,3). HCV infection that causes chronic liver diseases (4) as well as acute and chronic hepatitis, cirrhosis and hepatocellular carcinoma is a universal health problem (3). The World Health Organization $(\mathrm{WHO})$ reported that there were 71 million people with chronic HCV infection in 2017 (5). The global prevalence of anti-HCV was estimated at $1.6 \%$ for all ages corresponding to 115 million past viraemic infections (6).

Previous studies have found that HCV seroprevalence increased to $2.8 \%$ equating to more than 185 million infections worldwide $(7,8)$. Additionally, HCV is now considered to be pandemic and the $\mathrm{WHO}$ reported a world-wide prevalence of $3 \%$ (9). The WHO reported that areas with a high incidence of $\mathrm{HCV}$ infection included the Eastern Mediterranean Region (62.5 per 100.000) and the European Region (61.8 per 100.000) in 2017 (5).

Cyprus is a small island and is situated at the geographic crossroads of the three continents: Europe, Africa, and Asia. Furthermore, the rate of tourist and immigrant arrivals from Eastern Europe, the former Soviet Republics, Africa and Southeast Asia is relatively high (10). The majority of residents living in Cyprus belong to two ethnic groups, namely Turkish Cypriots and Greek Cypriots. The island has been divided into two regions due to the conflict between the two communities. As a result of this conflict, the Northern part of the island has since been under the control of its own government, and is called the Turkish Republic of Northern Cyprus (TRNC). The TRNC is officially recognised only by Turkey. Not only has Northern Cyprus become a destination for casino tourism and entertainment, but the country has experienced an influx of sex workers, particularly from Eastern Europe and 
the former Soviet Republics. In addition to the influx of visitors resulting from the growth in tourism, there are now 18 universities in the TRNC. The TRNC Ministry of Education has reported that there were 93.292 university students in the country in 2017, 53.135 of whom were Turkish and 27.538 were students of other nationalities.

The epidemiology and genotypes of the HCV infection in the TRNC are reviewed in this article, based on the published literature on this subject.

\section{Prevalence and Risk Factors for Hepatitis C Virus Infection in Northern Cyprus}

Cyprus is located in the Eastern Mediterranean Region and has a total population of approximately 800.000. Each year, the population is affected by the influx of immigrants, mainly due to tourism and politically displaced persons (2). The Northern Cyprus population has many similar characteristics to the population of Turkey, while there is also a close relationship with Southern Cyprus and Greece (11).

The Middle East region geographically consists of countries in Southwest Asia and parts of North Africa. In total, 17 million people are infected with chronic hepatitis $\mathrm{C}$ and 800.000 persons become infected with $\mathrm{HCV}$ each year in the Mediterranean Region (1). The epidemiology of HCV has been changed as a result of globalisation, based on the factors of modern transmission and worldwide human migration (2). The prevalence of the HCV infection varies according to different countries in the Middle East. In countries in the Middle East region such as Algeria, Egypt, Iran, Iraq, Israel, Jordan, Kuwait, Lebanon, Libya, Morocco, Oman, Palestine, Qatar, Saudi Arabia, Syria, Tunisia, Turkey, United Arab Emirates, and Yemen, the estimated prevalence of HCV in the general population is $2.7 \%$ (7). Another study indicated that the prevalence in the Middle East was between $1 \%$ and 4\%, except for Egypt (3). The countries with the highest prevalence were Egypt (14.7\%), Iraq (3.2\%) and Yemen (2.2\%). On the other hand, the lowest prevalence rates were reported to be in Qatar (0.9\%) and Turkey $(1.0 \%)(7)$.

The prevalence of $\mathrm{HCV}$ infection has been reported to be $1.6 \%$ in the Turkish population (12). Additionally, HCV prevalence has been reported to be between $1 \%$ and $1.5 \%$ in blood donors in Turkey (11). The HCV prevalence in Egypt has been reported to be approximately $14.7 \%$, which means that globally, it has the highest known prevalence rate of HCV (3). Additionally, HCV RNA prevalence rates ranged from $0.4 \%$ in countries such as Austria, Cyprus, Denmark, France, Germany and the United Kingdom to $2.9 \%$ in Romania according to a study by Lazarus et al. (13) in 2016. Epidemiological studies in Greece have suggested that the prevalence rate ranges between $0.5 \%$ and $2 \%$ (1).

Süer et al. (14) investigated the HCV seroprevalence among 1.500 blood donors in Northern Cyprus and reported that none of the donors were anti-HCV-positive. Altındis et al. (11) reported that the prevalence of HCV in Northern Cyprus was similar to that in Turkey and Greece. A study including soldiers from Turkey, blood donors from Northern Cyprus and soldiers from North Cyprus, reported an anti-HCV prevalence of $0.46 \%$ (11). Güler et al. (15) reported that the prevalence of anti-HCV was $0.9 \%$ among 16.400 individuals in Northern Cyprus. The present research studied the prevalence of $\mathrm{HCV}$ in thalassemia major patients and found that there were $11 \mathrm{HCV}$-positive patients in the sample group. Tınazlı et al. (16) reported that HCV antibodies were negative in 154 patients who had been admitted to a rheumatology ward in Northern Cyprus (16). These results indicated that the prevalence rate of $\mathrm{HCV}$ in Northern Cyprus was similar to the rates in Turkey and Greece.

\section{Distribution of Genotypes of Hepatitis C Virus Infection in Northern Cyprus}

$\mathrm{HCV}$ has seven genotypes according to the sequence of the viral genome $(3,7)$. Each genotype contains multiple subtypes, such as subtypes 1a and 1b (3). Genotype 1-3 has a worldwide circulation. On the other hand, genotypes 4-6 are restricted geographically and endemic infection is only found in specific countries (10). Additionally, only one genotype 7 infection has been reported in a Central African immigrant in Canada (7).

Worldwide, genotype 1 was identified in $46 \%$ of all infections, while the second most common was genotype 3 in 22\% of infections, followed by genotypes 2 and 4 in 13\% of infections each. Subtype $1 \mathrm{~b}$ was reported for $22 \%$ of all infections (6). Subtypes $1 \mathrm{~b}$ and genotype 2 are related with blood transfusions, specifically in older patients. Subtypes 1a and 3a are associated with transmission through injecting drug $(2,10)$.

Although genotypes 1, 2 and 3 have been reported worldwide, genotypes 4-6 have a more restricted distribution pattern (2). It has been reported that genotype 1 was prevalent in Australasia, Europe, Latin America and North America. Genotype 3 has been identified in $40 \%$ of all infections in Asia. Furthermore, genotype 4 has been frequently reported in North Africa and the Middle East, except Egypt. In Egypt, genotype 1 accounts for $46 \%$ of infections (6). HCV genotype 5 is most commonly found in South Africa (3). Finally, HCV genotype 6 has been reported to be prevalent in Southeast Asia (17).

$\mathrm{HCV}$ genotype 1 is commonly found in non-Arab Middle Eastern countries, including Turkey (82\%), Israel (68\%), Cyprus (68\%), and Iran (55\%) (3). Triantos et al. (1) reported that the genotype distribution in Greece was as follows: genotype 4 (13\%), genotype 2 (9\%), genotype 5 (1.2\%), and genotype 6 (0\%) (1). In Turkey, the most common genotype was genotype $1 \mathrm{~b}(67.7 \%)$, followed by genotype 1 (7.7\%), genotype 4 (7.3\%) and genotype 3 (6.7\%) (12). Furthermore, subtype $1 \mathrm{~b}$ was reported in Turkey, which may have been introduced to the country via virus transmission from Europe (18).

Altındis et al. (11) reported that genotype 1b (924\%) was the most commonly found genotype in their Northern Cyprus study group, which included civilians, Turkish soldiers and Northern Cyprus soldiers (11). A study analyzing the genetic heterogeneity of $\mathrm{HCV}$ infection in Cyprus found that 5 of the 6 known HCV genotypes, which include genotypes 1 and 4, were found in intravenous drug users with the $2 \mathrm{k} / 1 \mathrm{~b}$ recombinant strain (2). The most prevalent HCV genotype strain was genotype 1 (68\%), followed by genotype 3 in Cyprus, which is similar to that in the non-Arabic countries. The HCV genotype pattern may be associated with strains brought to the country by repatriated Cypriots, Cypriots who have visited other countries and tourists (3). 


\section{Treatment of Hepatitis C Virus Infection in Cyprus}

Effective antivirals are used in accordance with the established guidelines in the TRNC. Until January 2017, persons who were not citizens of the TRNC were not permitted to remain in the country if anti-HCV positivity was detected. As a result of the legislative amendments implemented in 2017, HCV treatment is now permitted in the TRNC if the infected individual either pays for the treatment or seeks treatment in the country of origin. If HCV-positive cases are successfully treated in the individuals' own country and obtain an HCV RNA negative result certificate, a TRNC residency permit can be granted.

\section{Conclusion}

Various studies and reports by the WHO have stated that $\mathrm{HCV}$ infections would be eradicated by 2030. In the TRNC, Altındis et al. (11) found HCV seroprevalence at a moderate frequency because of the fact that the case groups investigated in the study were predominantly Turkish soldiers. However, in the study group that Güler et al. (15) investigated, HCV seroprevalence was found to be low because the case group included TRNC citizens. The authors believe that the low prevalence of HCV in the TRNC was a result of the small island population and that individuals who are HCV-positive were not allowed to reside in the TRNC until 2017. Nevertheless, it is believed that there will be an increase in $\mathrm{HCV}$ seroprevalence going forward as well as an increase in the seroprevalence of hepatitis B surface antigen due to changes in the regulations surrounding residency permits in the TRNC in 2009. Furthermore, it is expected that there will be an increase in $\mathrm{HCV}$ seroprevalence due to relapses and cases of illegal immigration.

\section{Ethics}

Peer-review: Externally and internally peer-reviewed.

\section{Authorship Contributions}

Surgical and Medical Practices: M.G., K.S., Concept: M.G., K.S., Design: M.G., K.S., Data Collection or Processing: M.G., K.S., Analysis or Interpretation: M.G., K.S., Literature Search: M.G., K.S., Writing: M.G., K.S.

Conflict of Interest: No conflict of interest was declared by the authors.

Financial Disclosure: The authors declared that this study received no financial support.

\section{References}

1. Triantos C, Konstantakis C, Tselekouni P, Kaafateli M, Aggeletopoulou I, Manolakopoulos S. Epidemiology of hepatitis C in Greece. World J Gastroenterol. 2016;22:8094-8102.
2. Demetriou VL, van de Vijver DA; Cyprus HCV Network, Kostrikis LG. Molecular epidemioogy of hepatitis C infection in Cyprus: evidence of polyphyletic infection. J Med Virol. 2009;81:238248.

3. Ghaderi-Zefrehi H, Gholami-Fesharaki M, Sharafi H, Sadeghi F, Alavian SM. The Distribution of Hepatitis C Virus Genotypes in Middle Eastern Countries: A systemic Review and Meta-Analysis. Hepat Mon. 2016;16:e40357.

4. Güner R, Kayaaslan B. Current Treatment Approach in Acute Hepatitis C Infection. Viral Hepat J. 2017;23:1-5

5. World Health Organization. Global Hepatitis Report 2017.

6. Gower E, Estes C, Blach S, Razavi-Shearer K, Razavi H. Global Epidemiology and genotype distribution of the hepatitis $C$ virus infection. J Hepatol. 2014;61(Suppl):45-57.

7. Petruzziello A, Marigliano S, Loquercio G, Cozzolino A, Cacciapuoti C. Global epidemiology of hepatitis $C$ virus infection: An up-date of the distribution and circulation of hepatitis $\mathrm{C}$ virus genotypes. World J Gastroenterol. 2016;22:7824-7840.

8. Petruzziello A, Marigliano S, Loquercio G, Cacciapuoti C. Hepatitis $\mathrm{C}$ virus (HCV) genotypes distribution: an epidemiological up-date in Europe. Infectious Agents and Cancer. 2016;11:53.

9. Fallahian F, Najafi A. Epidemiology of Hepatitis $C$ in the Middle East. Saudi J Kindey Dis Transpl. 2011;22:1-9.

10. Demetriou VL, Kosktrikis LG. Molecular epidemiology of hepatitis $\mathrm{C}$ infection in Cyprus within the general population and high-risk cohorts. BMC Res Notes. 2011;4:468.

11. Altındis $M$, Yilmaz $S$, Dikengil $T$, Acemoglu $H$, Hosoglu $S$. Seroprevalence and genotyping of hepatitis $B$, hepatitis $C$ and HIV among health population and Turkish sodires in Northern Cyprus. World J Gastroenterol. 2006;12:6792-6796.

12. Ashkani-Esfahani S, Alavian SM, Salehi-Marzijarani M. Prevalence of hepatitis $C$ virus infection among hemodialysis patients in the Middle-East: A systemic review and meta-analysis. World J Gastroenterol. 2017;23:151-166.

13. Lazarus JV, Sperle I, Spina A, Rockstroh JK. Are the testing needs of key European population affected by hepatitis B and hepatitis $C$ being addressed ? A scoping review of testing studies in Europe. Croat Med J. 2016;57:442-456.

14. Süer K, Güvenir M, Güler E, Diktaş H. Evaluation of HBsAg, AntiHCV, Anti-HIV and Syphilis Test Results among the Blood Donors Admitted to the Near East University Hospital in Turkish Republic of Northern Cyprus. Klimik Dergisi. 2012;25:99-102.

15. Güler E, Güvenir M, Arıkan A, Uncu M, Aykaç A, Süer K. KKTC'deki HBV, HCV ve HIV Seroprevelansının 3 Yıllık Değerlendirilmesi. Infeksiyon Dünyası Çalıştayı 20-23 Mart 2014. P. 141.

16. Tınazlı M, Güvenir M, Aykaç A, Süer K. Hepatitis C Infection among patients admitted to a rheumatology ward in North Cyprus. The Egyptian Rheumatologist. 2017;39:245-247.

17. Huy TT, Abe K. Molecular Epidemiology of hepatitis B and C virus infections in Asia. Padiatr Int. 2004;46:223-230.

18. Ramia S, Eid-Fares J. Distribution of Hepatitis $C$ virus genotypes in the Middle East. Int J Infect Dis. 2006;10:272-277. 